\title{
Leadership Styles and Organizational Climate as Determinants of Job Involvement and Job Satisfaction of Workers in Tertiary Institutions
}

\author{
Benjamin O. Omolayo (Corresponding author) \\ Department of Psychology, Ekiti State University, Ado-Ekiti, Nigeria \\ Tel: 234-803-389-8781Ｅ-mail: droluomolayo@yahoo.com
}

Christiana K. Ajila

Department of Psychology, Ekiti State University, Ado-Ekiti, Nigeria

Tel: 234-703-673-9008Ｅ-mail: ajilakehinde@yahoo.com

Received: June 23, 2012

doi:10.5430/bmr.v1n3p28
Accepted: July 28, 2012

Online Published: August 1, 2012

\begin{abstract}
The study investigated leadership style and organizational climate as determinants of job involvement and job satisfaction of workers in tertiary institutions in Ekiti State, Nigeria. A total of 300 employees drawn from three educational institutions in Ekiti State participated in the study. They comprised of 150 male and 150 female. Four research instruments were used to collect data and responses from the research participants. The research instruments are Supervisory Behavior Description Questionnaire (SBDQ), Job Involvement Scale (JI). Minnesota Satisfaction Questionnaire (MSQ) and Index of Organizational Reaction (IQR). Results showed that leadership styles and organizational climate have significant influence on job satisfaction. Also, significant influence of leadership styles and organizational climate was found on job involvement. In the same vein, significant relationship was found between job satisfaction and organizational climate; between job satisfaction and job involvement; and between organizational climate and job involvement. However, there was no significant relationship between job satisfaction and leadership styles; and between job involvement and leadership styles. No significant difference existed between job involvement and leadership styles, and none existed between job satisfaction and leadership styles.
\end{abstract}

Keywords: Leadership styles, Organizational climate, Job satisfaction, Job involvement, Organization, Employees

\section{Introduction}

Organizations represent the most complex social structure known today because of their dynamic nature. Employees are key players in organizations, and it is through their involvement and commitment that organizations become competitive. The relationship between the organizations and people is however interdependent in nature (Kerego \& Mthupha, 1997), and both parties may impact on one another's ability to achieve positive results. Extensive research proved that job satisfaction doesn't happen in isolation, but it depends on organizational variables such as structure, size, pay (Zagenczyk \& Murrel, 2009), working conditions and leadership (Dimitriades 2007) which constitute organizational climate. Common to all organizations, be it formal or informal, service or industrial, is the presence of a leader. Their leader works through a group or groups to achieve organizational goals. To arrive at these goals, the leaders adopt one leadership style or another. Whatever leadership style (be it autocratic, democratic /participative, or laissez-faire) that is adopted will determine the sort of cooperation and relationship that will exist between the leaders and their subordinates. When an employee is hired by management to assist in the pre-determined organizational goals, he comes to the organization with his own personal goals, aspirations, biases and preferences. Each employee is concerned about his roles and commitment. It is the commitment of the organization to the employees and the function of the leader that marry employee's goals with that of the organization for harmonious co-existence. To accomplish this, the managers have to lead and direct effectively and efficiently.

Enns (2005) is of the view that manager's behaviors which were perceived as directive and restrictive correlated more with organizational climate and job involvement. Organizational climate also enhanced workers' performance, and the more zealous a worker is, the more is his effectiveness in the production. Organizational climate refers to the consensus of member perceptions about how a particular organization and/or its subsystems deal with its members 
and its external environment because the concept of organizational climate is based on individual perceptions. Srivasta (1994) studied a group of executives and supervisors and reported that overall organizational climate is positively related with job involvement. Eichar, Brody \& Fortinsky (1991) explored the effects of organizational climate on job satisfaction and they reported that those who scored high on organizational climate differed significantly on job satisfaction scale.

It is possible that the complexity of the concept of organizational climate includes precise measurement of the present. Nevertheless, it does seem to be a useful concept for achieving a better understanding of the behavior of people in organizations. Research suggests that climate is indeed a factor that influences employees' behavior and attitude, and substantial agreement has been found among employees as to the nature of any particular organization's climate (James, Joyce \& Slocum, 1988).

Job satisfaction describes how content an individual is with his/her job. There are varieties of factors that can influence a person's level of job satisfaction. Some of these factors include the level of pay and benefits, the perceived fairness of the promotion system within the organization, the quality of the working conditions, leadership and social relationships, and the job itself (the variety of tasks involved, the interest and challenge the job generates, and the clarity of the job description/requirements).

Adekanbi (2000) showed that employees with high level of job involvement are satisfied with their jobs. He further stressed that workers' job attitude depends on the nature of the duties as they have designed, the extent to which he has identify with the end result in his labor. According to him, satisfaction with one's job can mean an increased involvement in the fulfillment of formal requirements. Greater willingness to invest personal energy and time in job performance can also occur with having a satisfying job. Job satisfaction is a pleasurable positive state resulting from one's job experience. Thus individuals show pleasurable positive attitude when they are satisfied with their job (Weiss, 2002). Emery \& Barker (2007) described job satisfaction as an end state of feeling while Jha \& Pathak (2003) pointed out that job satisfaction is a part of life satisfaction, and the nature of one's environment off-the-job. Similarly, a job is an important part of life, and job satisfaction influences one's general life satisfaction. It is a general attitude which is the result of many specific attitudes (Jha \& Pathak, 2003). However, Emery \& Barker (2007) have suggested that a dynamic relationship exist between job satisfaction and organizational climate. Srivasta (1994) studied job satisfaction and organizational climate among executives and supervisors reported a significant positive relationship between the overall climate and job satisfaction. Job satisfaction was also found related to various individual dimension of organizational climate such as leadership, communication, interaction, influence in decision making, goal-setting and control (Srivasta, 1994).

The diverse expectations, goals and values that people bring with them to their jobs and the satisfaction they hope to derive from the job is a reflection of their job involvement (Chris \& Corr, 2002). Job involvement is the degree to which a person identifies psychologically with his/her work and the importance of the work in their total self-image (Lawler \& Hall, 1986). Zagenczyk \& Murrell (2009) investigated the relationship between advice-giving, advice-receiving and employee work attitude. They found that while advice-giving and advice-receiving were positively related to job involvement, only advice-receiving was positively related to work-unit commitment. Individuals may become involved in their jobs in response to specific attributes of the work situation (Mudrack, 2004).

The concepts of leadership, employee involvement, organizational climate and job satisfaction are very important factors in the life and survival of any organization. This is because the performance of an organization depends on the behavior and attitude of its workforce towards their assigned duties and the abilities of leaders to manage and retain its productive workers. An organization may have adequate planning, organizing and controlling procedure but may not survive because of poor leadership. Ineffective leadership account for most of the organizational failures, and this is a serious obstacle to organizational development. Human resources which encompass the entire workforce are important factor in the life of organizations. However, a major concern to management in organizations is the negative attitude of employees towards work. A worker that is dissatisfied may develop negative attitude towards his/her work with characteristics behavioural manifestations such as low job involvement, absenteeism and intention to leave the organization.

The purpose of this study is to investigate the extent at which leadership styles will influence job involvement and job satisfaction of workers, to examine the influence of organizational climate on job involvement and job satisfaction, and to examine the interaction effect of leadership styles and organizational climate on job involvement and job satisfaction of workers in tertiary institutions. 


\section{Hypotheses}

The following hypotheses were tested statistically.

i. There will be a significant influence of leadership styles (autocratic and democratic) and organizational climate on job satisfaction.

ii. There will be a significant influence of leadership styles (autocratic and democratic) and organizational climate on job involvement.

iii. There will be a significant relationship among the predictor variables (leadership styles and organizational climate) and the criterion variables (job satisfaction and job involvement).

iv. There will be a significant difference between leadership styles (autocratic and democratic) and job involvement.

v. There will be a significant difference between leadership styles (autocratic and democratic) and job satisfaction.

\section{Methods}

\subsection{Design}

Descriptive survey design was adopted with the use of questionnaire to generate data and response from the research participants. Leadership styles (autocratic and democratic) and organizational climate (conducive/positive and discomfort/negative) are the independent variables while the dependent variables are job involvement and job satisfaction.

\subsection{Setting}

The research was carried out in three selected educational institutions in Ekiti State, Nigeria, namely Ekiti State University, The Federal Polytechnic and School of Nursing, all in Ado-Ekiti in Ekiti State, Nigeria.

\subsection{Participants}

300 randomly selected workers from the research settings participated in the study. They were made up of 150 male and 150 female with their age ranges between 20 years and 50 years. The participants comprised of both married and single workers with a minimum educational level of Senior Secondary School Certificate and University degree as the maximum educational qualification.

\subsection{Instruments}

Four standardized research instruments were used to collect data and responses from the research participants .The instruments are:

i. Supervisory Behavior Descriptive Questionnaire (SBDQ) developed by Fleischman (1953). It was designed to assess two different kind of specific leadership styles in work organizations, namely Autocratic and Democratic leadership styles. Fleishman obtained a test-retest reliability coefficient of .75 for autocratic leadership style and .87 for democratic leadership style for American samples while Omolayo (2004) reported a test-retest reliability coefficient of .65 (autocratic) and .74 (democratic) for Nigerian samples. Ejimofor (1987) correlated the SBDQ with Organizational Commitment questionnaire (OC) to obtain concurrent validity coefficient of .336 for autocratic and .142 for democratic leadership styles.

ii. Minnesota Satisfaction Questionnaire (MSQ) developed by Weiss, Dawis, England \& Lofquist (1967). The scale is subdivided into 3 namely intrinsic satisfaction (I) extrinsic satisfaction (E), and general satisfaction (G). Weiss et al (1967) provided the psychometric properties for American samples while Mogaji (1997) provided the properties for Nigerian samples. Weiss et al (1967) reported a one week interval test-retest reliability coefficient of 0.89 and one-year interval coefficient of 0.70 . Mogaji (1997) reported 72 days interval test-retest reliability coefficient of .69 (Intrinsic satisfaction), .82 (Extrinsic satisfaction) and .94 (General satisfaction) for Nigerian samples. By correlating MSQ with Job Description Index (JDI), the concurrent validity obtained by Wanous (1974) for American samples is .71 while Mogaji (1997) reported a concurrent validity of .50 for Nigerian samples.

iii. Job Involvement Scale (JI) developed Lodahl \& Kejner (1965). It was designed to measure the extent to which a person is attached to his/her job. The coefficient of test-retest reliability obtained in an interval of 72 days is .90 (Lodahl \& Kejner, 1965). 
iv. Index of Organizational Reactions (IOR) developed by Smith (1976). It measure some aspects of work namely Supervision (S), Company identification (Ci), Kind of work (Kw), Amount of work (Aw), Co-workers (Co), Physical work conditions (P), Financial rewards (Fr) and Career future (Cf). The test-retest reliability reported by Mogaji (1997) for Nigerian samples are $.87(\mathrm{~S}), .89(\mathrm{Ci}), .91(\mathrm{Kw}), .85$ (Aw), .88 (Co), $.99(\mathrm{P}), .87(\mathrm{Fr})$ and $.85(\mathrm{Cf})$.

\subsection{Statistical Analysis}

t-test for independent groups, Pearson product moment correlation and Regression analysis were used to analyze the data collected, and to test for the hypotheses formulated.

\section{Results}

Table 1: Table showing the influence of leadership styles and organizational climate on job satisfaction.

\section{$<$ Table 1 here $>$}

From Table 1, result shows a significant influence of the two leadership styles and organizational climate on job satisfaction. This means that leadership styles and organizational climate has influence on the job satisfaction of workers in tertiary institutions.

Table 2: Table showing the influence of leadership styles and organizational climate on job involvement

$<$ Table 2 here $>$

Result as shown in Table 2 revealed a significant influence of the two leadership styles and organizational climate on job involvement. This indicates that both leadership styles and organizational climate influence the job involvement of workers in tertiary institutions.

Table 3: Table showing the significant relationship among the predictor variables (leadership styles and organizational climate) and criterion variables (job involvement and job satisfaction)

\section{$<$ Table 3 here $>$}

Table 4: Table showing the correlation between the predictor variables and criterion variables.

$$
<\text { Table } 4 \text { here }>
$$

From Table 4, result shows that significant relationship exist between job satisfaction and organizational climate. Also, the result revealed a significant relationship between job satisfaction and job involvement; and between organizational climate and job involvement. However, there is no significant relationship between job satisfaction and leadership styles; and between job involvement and leadership styles.

Table 5: Table showing the difference between leadership styles (autocratic and democratic) and job involvement

$<$ Table 5 here $>$

Result as shown in Table 5 revealed that there is no significant difference between leadership styles (autocratic and democratic) and job involvement. This indicates that the style of leadership does not affect job involvement of workers.

Table 6: Table showing the difference between leadership styles (autocratic and democratic) and job satisfaction

$$
<\text { Table } 6 \text { here }>
$$

Table 6 shows that there is no significant difference between leadership styles (autocratic and democratic) and job satisfaction. This means that leadership styles do not affect the satisfaction of workers on the job.

\section{Discussion}

The result of hypotheses one and two shows the influence of the two leadership styles (autocratic and democratic) and organizational climate on job involvement and job satisfaction. This means that subordinates tends to exhibit a more positive attitude towards their duties when they are given high consideration in policy making, encouraged by their leaders and allowed to participate in decision making on issues that concern them, and when the climate condition of the organization is conducive than they are supervised in a very stern way and made to carry out orders without their prior knowledge or opinion. This findings of this study corroborated McGregor's (1960) theory X and $\mathrm{Y}$ which posits that a manager's style of leadership was the determinant of subordinate's behavior and that subordinates would respond accordingly to supervision they are subjected to. According to McGregor, if a manager treats his subordinates well, the subordinates would behave accordingly, but if a manager treats his subordinates as if they are not responsible individuals, they would fulfill those expectations. The finding of this study also gives 
support to the findings of Williams (2002). His research reveals that when subordinates were subjected to two leadership styles (autocratic and democratic) and good climate, they differ significantly in their preference of supervision as most of the participants showed a higher preference for the democratic leader over the authoritarian. This result supports the findings of Mauno, Kinnunen, Wanous \& Natti (2005) who found a correlation between job involvement and job satisfaction.

De Witte (2005) also found out in his study that subordinates behave in accordance with the directive given by their leaders and the climate conditions of the organizations. He also stated that subordinates' behavior in term of their environment and satisfaction to organizational goals and objectives is influenced by their perceptions of the power applied by their leaders and the climate condition of the organization. The level of job involvement and job satisfaction of the workers of the participating organizations of this study is related positively to the kind of power exerted over them by their leaders in term of democratic and autocratic dimension and the subsisting organizational climate in the organizations.

The third hypothesis which states that there will be a significant relationship among the predictor variables and the criterion variables shows that there is a significant relationship between job satisfaction and job involvement, between job satisfaction and organizational climate, and between organizational climate and job involvement. However, no significant relationship exists between job satisfaction and any of the leadership styles (autocratic and democratic). Similarly, no significant relationship was found between job involvement and leadership styles (autocratic and democratic). The plausible explanation for the existence of no relationship between job satisfaction and leadership styles is based on the belief that there are numerous leadership possibilities and that there are many leaders within the educational institutions. This is because leadership is not role specific reserved only for administrators, rather, the job of the leaders in educational institutions is to fashion learning opportunities for the faculty and staff so they can develop into productive leaders. Thus in tertiary institutions, the Principal Officers such as the Vice-Chancellors, Rectors, Principals, Deputy Vice-Chancellors, Deputy Rectors, Vice-Principals, Registrars, Bursars, Librarians, Heads of Departments/Units, and even Lecturers and Teachers are seen as leaders. This supports the view of Ash \& Persall (2000).

The result of the fourth hypothesis revealed that no significant difference exist between leadership styles (autocratic and democratic) and job involvement. This finding indicates that having high job involvement makes a job to become the personal identity of the employees. If identity crosses situational boundaries, the job role of a person with high job involvement will also cross situational boundaries. If this is the case, then job involvement reduces segmentation of the job role. Therefore, as job involvement increases, the potential for segmentation may decrease, and as segmentation decreases, job satisfaction may rise.

The result of the fifth hypothesis basically reveals that there is no significant difference leadership styles (autocratic and democratic) and job satisfaction. This result contradicts that of Starrat (2001) whose study showed that highly satisfied and more involved workers largely depend on the leaders.

\section{Conclusion}

From the result of this study, the following conclusions are made.

i. Autocratic and democratic type of leadership and organizational climate jointly has an influence on job satisfaction.

ii. There is a significant joint influence of leadership styles (autocratic and democratic) and organizational climate on job involvement.

iii. There is a significant relationship between job satisfaction and organizational climate.

iv. There is a significant relationship between job satisfaction and job involvement.

v. There is a significant relationship between organizational climate and job involvement.

vi. There is no significant relationship between job satisfaction and leadership styles (autocratic and democratic).

vii. There is no significant relationship between job involvement and leadership styles (autocratic and democratic).

viii. No significant difference exists between autocratic and democratic leadership styles and job satisfaction.

ix. There is no significant difference between autocratic and democratic leadership styles and job involvement.

$\mathrm{x}$. There is no significant difference between autocratic and democratic leadership styles and job satisfaction. 


\section{Limitations}

There are limitations in this study. These include:

i. The research setting is limited to only three educational institutions in Ado-Ekiti, Ekiti state. There are other institutions in the state that does not reside in Ado-Ekiti.

ii. The number of participants used in this study is low compare to the population of workers in the three institutions selected.

iii. The job satisfaction and job involvement level of male and female workers (gender), and married and single workers (marital status) were not determined.

\section{Recommendations}

In view of the findings of this research work, it is recommended that:

(1) Attention should be paid to leadership in the management of human resources in order to attain organizational effectiveness. Organizing and embarking on leadership training and development programs particularly in areas that are concerned with human behavior at work.

(2) Leaders in organizations should have a proper and appropriate orientation on the essence and importance of good leadership, and in maintaining a cordial relationship with their subordinates, who are important assets to the organization.

(3) Managers who are known for being autocratic in their style of administration and supervision should be ready to adjust positively. This is to make workers see their job as a central life interest and consequently identify more with the goals of the organization. In so doing, workers would tend to put in better performance and the seemingly intractable problems of employee turn-over in organizations would be ameliorated.

(4) Leaders in organizations should take into cognizance their subordinates evaluation, expectations and perception of them from time to time so as to know the feelings of their style of supervision, and make necessary adjustments where applicable.

\section{References}

Adekanbi, J.A. (2000). Organizational behavior: Understanding and application. Ondo: Sylva Publisher Limited, $37-45$.

Ash, R. \& Persall, M. (2000). Developing teachers' leaders: The Principal as Chief Learning Officer. NASSP Bulletin, May Edition, 15-23.

Chris, J. \& Corr, P. (2002). Global job satisfaction and facet description: The moderating role of facet importance. Journal of Applied Psychology, 92, 161-170.

De White, H. (2005). Job insecurity: Review of the international literature on definition, prevalence, antecedent and consequences. South African Journal of Industrial Psychology, 52-68.

Dimitriades, Z.S. (2007). The influence of service climate and job involvement on customer oriented organizational citizenship behavior in service organizations: A survey. Employees' Relations. 98.

Eichar, D.M., Brody, E.M. \& Fortinsky, R.H. (1991). The job satisfaction of older workers. Journal of Organizational Behaviour, 12, 609-620. http://dx.doi.org/10.1002/job.4030120705

Ejimofor, B.I. (1987). Organization commitment as a function of leadership styles in Nigerian organizations. University of Lagos.

Emery, C.R. \& Barker, K.J. (2007). Effect of commitment, job involvement and teams on customer satisfaction and profit. Team performance management, 13(3\&4), 90-101. http://dx.doi.org/10.1108/13527590710759847

Enns, A.V. (2005). Organizational commitment as a function of leadership style in Nigeria organizations: A study of three commercial banks in Lagos. University of Lagos.

Fleishman, E.A. (1953). The description of supervisory behaviour. Journal of Applied Psychology, 37, 1-6. http://dx.doi.org/10.1037/h0056314

James, L.R., Joyce, W.F., \& Slocum, J.R. (1988). Comments organizations do not recognize. Academy of Management Review, 13, 129-132. http://dx.doi.org/10.2307/258360, http://dx.doi.org/10.5465/AMR.1988.4306808 
Jha, P. \& Pathak, G.W. (2003). A comparative study of job satisfaction in the post-liberation scenario among executive of private and public sector organizations. Journal of Indian Management Studies, 7, 21-31.

Kerego, K. \& Mthupha, D.M. (1997). Job satisfaction as perceived by agricultural extension workers in Swaziland. South African Journal of Agricultural Extension, 23(2), 19-24.

Lawler, E.E. \& Hall, D.T. (1986). Relationship of job characteristics, job involvement, job satisfaction and intrinsic motivation. Journal of Applied Psychology, 54, 305-312. http://dx.doi.org/10.1037/h0029692

Lodhal, T.M. \& Kejner, M. (1965). The definition and measurement of job involvement. Journal of Applied Psychology, 49, 24-33. http://dx.doi.org/10.1037/h0021692, PMid: 14279757

Mauno,S., Kinnunen, U., Wanous,E. \& Natti, J. (2005). Psychological consequences of fixed-term employment and job insecurity among health care staff. European Journal of Work and Organizational Psychology, 14, 209-237. http://dx.doi.org/10.1080/13594320500146649

McGregor, D. (1960). The human side of enterprise. New York: McGraw Hill.

Mogaji, A.A. (1997). Effects of organizational climate on employee's commitment, involvement and motivation in some Nigerian manufacturing industries. University of Lagos.

Mudrack, P.E. (2004). Job involvement, obsessive-compulsive personality traits and workaholic behavioral tendencies. Journal of Organizational Change Management, 17(5), 490-580. http://dx.doi.org/10.1108/09534810410554506

Omolayo, B.O. (2004). Influence of job variables on workers'commitment and satisfaction in four selected Nigerian manufacturing industries. University of Ado-Ekiti.

Smith, F.J. (1976). Index of Organization Reaction (IOR). JSAS catalog of selected documents in Psychology.

Srivastava, S.K. (1994). Correlational study of organizational climate and need satisfaction with job involvement. Paper presented at Asian IAAP Conference, Aligarh, Feb. 27-29.

Starrat, R. (2001). Democratic leadership theory in late modernity: An oxymoron or ironic possibility? International Journal of Leadership in Education. 4(4), 333-352. http://dx.doi.org/10.1080/1360312011080978

Wanous, J.P. (1974). A causal-correlation analysis of the job satisfaction and performance relationship. Journal of Applied Psychology, 59, 139-144. http://dx.doi.org/10.1037/h0036532

Weiss, H.M. (2002). Deconstructing job satisfaction: Separating evaluations, beliefs and affective experiences. Human Resource Management Review, 12, 173-194. http://dx.doi.org/10.1016/S1053-4822(02)00045-1

Weiss, D.J., Dawis, R.V., England, G.W. \& Lofquist, L.H. (1967). Manual for the Minnesota Satisfaction Questionnaire. Minnesota IRC: University of Minnesota.

Williams, J. (2002). Improving safety leadership. Professional Safety, 47(4), 43-48.

Zagenczyk, T.J. \& Murrell, A.J. (2009). It is better to receive than to give: Advice network effects on job and work -unit attachment. Journal of Business Psychology, 26, 101-124.

Table 1. Table showing the influence of leadership styles and organizational climate on job satisfaction

\begin{tabular}{|l|l|l|l|l|l|l|l|}
\hline Source & $\beta$ & $\mathrm{T}$ & $\mathrm{P}$ & $\mathrm{r}$ & $\mathrm{R} 2$ & $\mathrm{~F}$ & $\mathrm{P}$ \\
\hline Autocratic & -.033 & -.58 & $>.05$ & & & & \\
\hline Democratic & -.52 & -.89 & $>.05$ & .206 & .042 & 4.36 & $<.05$ \\
\hline $\begin{array}{l}\text { Organizational } \\
\text { reaction }\end{array}$ & .201 & 3.52 & $<.05$ & & & & \\
\hline
\end{tabular}

$\mathrm{R}(3,298)=4.36, \mathrm{p}<.05$ 
Table 2. Table showing the influence of leadership styles and organizational climate on job involvement

\begin{tabular}{|l|l|l|l|l|l|l|l|}
\hline Source & $\beta$ & $\mathrm{T}$ & $\mathrm{P}$ & $\mathrm{r}$ & $\mathrm{R} 2$ & $\mathrm{~F}$ & $\mathrm{P}$ \\
\hline Autocratic & -.058 & -1.04 & $>.05$ & & & & \\
\hline Democratic & .006 & .11 & $>.05$ & .318 & .101 & 11.13 & $<.05$ \\
\hline $\begin{array}{l}\text { Organizational } \\
\text { reaction }\end{array}$ & -.314 & -5.69 & $<.05$ & & & & \\
\hline
\end{tabular}

$\mathrm{R}(3,299)=11.13, \mathrm{p}<.05$

Table 3. Table showing the significant relationship among the predictor variables (leadership styles and organizational climate) and criterion variables (job involvement and job satisfaction)

\begin{tabular}{|l|l|l|l|}
\hline & Mean & Std. Deviation & N \\
\hline Job satisfaction & 69.9900 & 11.0157 & 299 \\
\hline Autocratic & 78.1733 & 23.2858 & 300 \\
\hline Democratic & 91.4500 & 22.8444 & 300 \\
\hline Organizational reaction & 123.3467 & 16.1533 & 300 \\
\hline Job involvement & 48.4867 & 7.7871 & 300 \\
\hline
\end{tabular}

Table 4. Table showing the correlation between the predictor variables and criterion variables

\begin{tabular}{|c|c|c|c|c|c|}
\hline & Job satisfaction & Autocratic & Democratic & $\begin{array}{l}\text { Org. } \\
\text { reaction }\end{array}$ & Job involvement \\
\hline $\begin{array}{l}\text { Job satisfaction: Pearson correlation } \\
\text { Sig. (2-tailed) } \\
\text { N }\end{array}$ & $\begin{array}{l}1.000 \\
299\end{array}$ & & & & \\
\hline $\begin{array}{l}\text { Autocratic: Pearson correlation } \\
\text { Sig. (2-tailed) } \\
\text { N }\end{array}$ & $\begin{array}{l}-.029 \\
.613>.05 \\
299\end{array}$ & $\begin{array}{l}1.000 \\
300\end{array}$ & & & \\
\hline $\begin{array}{l}\text { Democratic: Pearson correlation } \\
\text { Sig. (2-tailed) } \\
\mathrm{N}\end{array}$ & $\begin{array}{l}-.032 \\
.576>.05 \\
299\end{array}$ & $\begin{array}{l}-136 * \\
.018>.05 \\
300\end{array}$ & $\begin{array}{l}1.000 \\
300\end{array}$ & & \\
\hline $\begin{array}{l}\text { Org.reaction: Pearson correlation } \\
\text { Sig. (2-tailed) } \\
\mathrm{N}\end{array}$ & $\begin{array}{l}.198 * * \\
.001>.05 \\
299\end{array}$ & $\begin{array}{l}-.015 \\
.799>.05 \\
300\end{array}$ & $\begin{array}{l}.068 \\
.241 \\
300\end{array}$ & $\begin{array}{l}1.000 \\
300\end{array}$ & \\
\hline $\begin{array}{l}\text { Job involvement: Pearson correlation } \\
\text { Sig. (2-tailed) } \\
\text { N }\end{array}$ & $\begin{array}{l}-297 * * \\
.000<.01 \\
299\end{array}$ & $\begin{array}{l}-.054 \\
.351>.05 \\
300\end{array}$ & $\begin{array}{l}-.007 \\
.897>.05 \\
300\end{array}$ & $\begin{array}{l}-.313 * * \\
.000<.01 \\
300\end{array}$ & $\begin{array}{l}1.000 \\
300\end{array}$ \\
\hline
\end{tabular}

* Correlation is significant at 0.01 level (2-tailed)

** Correlation is significant at 0.05 level (2-tailed) 
Table 5. Table showing the difference between leadership styles (autocratic and democratic) and job involvement

\begin{tabular}{|c|c|c|c|c|c|c|c|}
\hline Variables & $\mathrm{N}$ & $\mathrm{X}$ & $\mathrm{SD}$ & $\mathrm{SE}$ & $\mathrm{df}$ & $\mathrm{tc}$ & $\mathrm{P}$ \\
\hline Autocratic & 259 & 48.53 & 7.71 & .48 & & & \\
& & & & & 297 & .24 & $>.05$ \\
Democratic & 41 & 48.22 & 8.36 & 1.31 & & & \\
\hline
\end{tabular}

Table 6. Table showing the difference between leadership styles (autocratic and democratic) and job satisfaction

\begin{tabular}{|c|c|c|c|c|c|c|c|}
\hline Variables & $\mathrm{N}$ & $\mathrm{X}$ & $\mathrm{SD}$ & $\mathrm{SE}$ & $\mathrm{df}$ & tc & $\mathrm{P}$ \\
\hline Autocratic & 259 & 70.33 & 10.84 & .67 & & & \\
Democratic & 41 & 67.77 & 11.99 & 1.89 & 297 & 1.37 & $>.05$ \\
& & & & & & & \\
\hline
\end{tabular}

$\mathrm{t}=1.37, \mathrm{p}<.05$ 